\title{
ANALISIS SISTEM INFORMASI AKUNTANSI PEMBELIAN DAN PENJUALAN PADA CV. TRI KENCANA CILEGON-BANTEN
}

\author{
M. HendraYulianto \\ Darti Djuharni* \\ Sekolah Tinggi Ilmu Ekonomi (STIE) Malangkuçeçwara, \\ Jalan Terusan Candi Kalasan, Malang \\ dartidjuharni@yahoo.com
}

\author{
A R T I C L E I N F O \\ Article history \\ Received September 12, 2018 \\ Revised November 10, 2018 \\ Accepted November 17, 2018
}

Key words:

Accounting Information System, Cycle of Purchase and Selling, Internal Control System

\begin{abstract}
A B S T R A C T
The purpose of this study is to analyze and evaluate the implementation of accounting information system for purchases and sales in "CV. TRI KENCANA. The research method used a case study method with descriptive analysis. The results show that many accounting information systemsof purchases and sales carried out in this company are still a lot of weakness, including the uneven division of tasks in accordance with the existing organizational structure, there are multiple functions in several division, there are two departments whose authority and duties are the same but in the organizational structure is separated. Besides, the documents used there are still shortcomings related to internal control that must be done. Therefore in this study, several solutions were provided to overcome the problems, namely, improvement of the organizational structure both in terms of naming, division of tasks, and the incorporation of two departments that have the same function, as well as refinement of the documents used.
\end{abstract}

\section{A B S T R A K}

Tujuan penelitian ini adalah untuk menganalisis dan mengevaluasipelaksanaan sistem informasi akuntansi pembelian dan penjualan yang ada pada "CV. TRI KENCANA.Metode penelitian yang digunakan adalah studi kasus dengan menggunakan analisis deskriptif dalam menjawab tujuan. Hasil penelitian menunjukkan bahwa SIA pembelian dan penjualan yang dijalankan pada perusahaan ini masih banyak kelembahan, diantaranya pembagian tugas sesuai dengan struktur organisasi yang ada tidak merata, ada perangkapan fungsi di beberapa bagian, ada dua bagian yang wewenang dan tugasnya sama tetapi di struktur organisasi dipisahkan. Selain itu dokumen yang digunakan masih terdapat kekurangan terkait dengan pengendalian internal yang harus dilakukan. Oleh karena itu dalam penelitian ini diberikan beberapa solusi untuk mengatasi persoalan yang dihadapi yaitu, penyempurnaan struktur organisasi baik dalam hal penamaan, pembagian tugas, maupun penggabungan dua bagian yang memiliki fungsi yang sama, serta penyempurnaan dokumen yang digunakan.

\section{PENDAHULUAN}

Suatu organisasi sangat tergantung pada sistem informasi untuk dapat berdaya saing (Bodnar dan Hopwood, 2006). Selanjutnya dia mengatakan bahwa salah satu faktor penting untuk mempertahankan daya saing bagi perusahaan adalah produktivitas. Produktivitas dapat ditingkatkan dengan menerapkan sistem kerja yang baik (Mindhayani dan Purnomo, 2016). Di dalam perusahan dagang salah satu faktor yang mempengaruhi produktivitas adalah aktivitas transaksi pembelian dan penjualan. Untuk itu sistem kerja pada kegiatan oprasional pembelian dan penjualan perlu ditingkatkan.
Peningkatan sistem kerja pada transaksi pembelian dan penjualan dapat dilakukan dengan menerapkan sistem informasi akuntansi (SIA) yang baik. SIA yang baik dapat meningkatkan kualitas dan biaya produk atau jasa, meningkatkan efisiensi dan efektivitas rantai pasokan barang, serta meningkatkan struktur pengendalian internal (Romney dan Steinbart, 2015). Penerapan sistem informasi akuntansi juga dimaksudkan untuk menyelesaikan permasalahan yang ada. Permasalahan pada transaksi pembelian menurut Masrunik (2017) antara lain, manipulasi pembelian barang, kualitas, kuantitas, spesifikasi, harga, dan penyalahgunaan 
fungsi yang mungkin akan timbul dalam transaksi pembelian. Permasalahan yang dijelaskan pada kalimat sebelumnya dapat diatasi dengan penerapan sistem informasi akuntansi yang baik. Hal ini sebagaimana diungkap oleh Suprono (2015) sistem informasi akuntansi pembelian yang baik dapat meningkatkan pengendalian manajemen untuk meminimalisir penyelewengan-penyelewengan. Penyelesaian permasalahan yang ada pada transaksi pembelian sangat penting mengingat transaksi pembelian merupakan transaksi yang dilakukan untuk memperoleh pasokan barang yang nantinya akan dijual agar memperoleh keuntungan, sehingga nantinya akan berpengaruh juga terhadap perolehan pendapatan perusahaan.

Untuk memaksimumkan perolehan pendapatan dibutuhkan prosedur, ketelitian, dan pengendalian penjualan yang berkualitas.Wardani (2014) menyatakan dibutuhkan ketelitian untuk menghindari kecurangan pada penjualan yang akanmenyebabkan kerugian. Disisi lain Lathifah (2015) menyatakan pelaksanaan prosedur penjualan yang tidak sesuai dengan standar yang ditetapkan akan menjadi masalah bagi perusahaan. Permasalahan yang muncul dalam transaksi penjualan menurut Romney and Steinbart (2004) antara lain pesanan yang tidak akurat, jumlah piutang tak tertagih, dan pencurian kas. Garcia, Nangoi, and Tirayoh (2016)yang menyatakan sistem informasi akuntasi penjualan dan pengendalian penjualan yang tepat akanmampu menghasilkan pendapatan yang maksimal bagi perusahaan.Begitu juga yang diungkapkan oleh Hastoni and Aprilisabeth (2008) sistem informasi akuntansi penjualan yang baik dapat meningkatkan evektivitas pengendalian intern piutang dan penerimaan

\section{KAJIAN LITERATUR DAN PENGEMBANGAN HIPOTESIS}

Sistem merupakan suatu jaringan prosedur yang dibuat menurut pola yang terpadu untuk melaksanakan kegiatan pokok perusahaan (Lathifah, 2015).Sistem juga merupakan suatu kerangka dari prosedur yang saling berhubungan dan disusun sesuai sekema yang menyeluruh untuk melaksanakan kegiatan (Fitriyati, 2013). Sedangkan menurut Kusasi and Rahman (2018) sistem adalah suatu kegiatan dari prosedur-prosedur yang saling berhubungan dan sesuai dengan skema yang menyeluruh untuk melaksanakan suatu kegiatan atau fungsi utama dari perusahaan yang dihasilkan oleh suatu proses tertentu. Sedangkan masih menurut dia bahwa pengertian informasi adalah data yang diproses menjadi suatu bentuk kas. Hal ini di perkuat pula oleh pernyataan Hasanah dan Siswanto (2012) bahwa sistem akuntansi penjualan tunai terkomputerisasi dapat menyajikan informasi relevan dan akurat.

Sari, Djazari dan Sukirno (2005) dalam penelitianya tentang Analisis Sistem Akuntansi Pembelian menyimpulkan dengan menerapkan sistem pembelian yang baik dapat mendorong efisiensi, ketelitian, keandalan data akuntansi, meningkatkan pengendalian internal, serta dapat menjaga kekayaan perusahaan. Di sisi lain Alianto, Wijaya dan Arlan (2012) dalam penelitian tentang An Analysis Of Sales Information System and Competitive Advantage menyimpulkan bahwa sistem informasi akuntansi penjualan akan meningkatkan kinerja perusahaan dan pada akhirnya dapat meningkatkan daya saing perusahaan studi kasus pada UD. Citra Helmet. Berdasarkan hasil penelitian yang telah diuraikan sebelumnya dan mengingat pentingnya memperhatikan efisiensi dan efektifitas dalam pelaksanaan SIA pembelilan dan penjualan, maka dalam kajian ini peneliti melakukan SIA pembelian dan penjualan pada CV. Tri Kencana. Hal ini dilakukan karena di perusahaan ini sering timbul masalah pada aktivitas pembelian dan penjualannya.

Berdasarkan latar belakang yang diuraikan sebelumnya maka rumusan masalah dalam penelitian ini adalah: "bagaimana sistem informasi akuntansi pembelian dan penjualan yang diterapkan pada "CV. TRI KENCANA"? Dengan demikian tujuan penelitian ini adalah menganalisis dan mengevaluasipelaksanaan sistem informasi akuntansi pembelian dan penjualan yang ada pada "CV. TRI KENCANA".

yang lebih berguna dan berarti bagi yang menerimanya dalam aktivitas pembuatan keputusan.Berdasarkan uraian sebelumnya sistem informasidapat diartikan sebagai suatu sistem yang menyediakan informasi untuk manajemen pengambilan keputusan/kebijakan dan menjalankan operasional dari kombinasi orang-orang, teknologi informasi dan prosedur-prosedur yang terorganisasi. Sistem informasi perlu diterapkan pada proses akuntansi untuk dapat meningatkan kualitas. Penerapan sistem informasi pada proses akuntansi disebut dengan sistem informasi akuntansi.

Bodnar and Hopwood (2006) menyatakan bahwa sistem informasi akuntansi merupakan kumpulan sumber daya, seperti manusia dan peralatan untuk mengubah data keuangan dan data lainya kedalam informasi yang nantinya 
akandikomunikasikan kepada para pembuat keputusan.Sementara itu Viola, Ekawati, and Wijaya (2017) menyatakan sistem informasi akuntansi adalah suatu sistem yang mengumpulkan dan menginformasikan data keuangan dari setiap transaksi keuangan. Pernyataan tersebut didukung Ambarwati and Isharijadi (2012) yang menyatakan bahwa sistem informasi akuntansi adalah susunan dari bagian-bagian seperti manusia dan berbagai peralatan yang digunakan untuk memproses data menjadi informasi keuangan yang bermanfaat untuk pengambilan keputusan.Sistem informasi akuntansi pada dasarnya dibangun untuk mencapai tujuan perusahaan. Tujuan utama dari suatu perusahaan menurut Kusasi and Rahman (2018) adalah mengolah data akuntansi yang berasal dari berbagai sumber menjadi informasi akuntansi yang diperlukan oleh berbagai macam pemakai, dan untuk mengurangi resiko pada saat pengambilan keputusan.

Di sisi lain Alianto, Wijaya dan Arlan (2012) menyatakan, penggunaan sistem informasi yang terintegrasi akan meningkatkan efektifitas dan efisiensi, seperti ketersediaan informasi secara tepat dan akurat.Romney and Steinbart (2015) menyebutkan ada enam komponen utama dalam kegiatan sistem informasi akuntansi yang diuraikan sebagai berikut. Orang yang menggunakan sistem, Prosedur dan intruksi yang digunakan untuk mengumpulkan, memproses, dan menyimpan data, Data mengenai organisasi dan aktivitas bisnisnya, Perangkat lunak yang digunakan untuk mengolah data, Infrastruktur teknologi informasi meliputi komputer, perangkat peripheral, dan perangkat jaringan komunikasi yang digunakan dalam sistem informasi akuntansi, Pengendalian internal dan pengukuran keamanan yang menyimpan data sistem informasi akuntansi.

Enam komponen tersebut sangat berguna bagi perusahaan untuk memenuhi kebutuhan dalam mengelola sumber daya, data, dan pengendalian internal yang ada. Romney and Steinbart (2015) selanjutnya menyatakan bahwa enam komponen tersebut memungkinkan sistem informasi akuntansi untuk memenuhi tiga aktifitas penting yaitu, mengumpulkan dan menyimpan data mengenai aktivitas, sumber daya, dan personel organisasi; mengubah data menjadi informasi sehingga manajemen dapat merencanakan, mengeksekusi, mengendalikan, serta mengevaluasi aktivitas, sumber daya dan personel; dan memberikan pengendalian yang memadai untuk mengamankan asset dan data organisasi. Terkait dengan SIA Pembelian yang menurut Sari, Djazari dan Sukirno (2005) merupa- kan penggunaan sistem manusia, serta modal dan mesin yang terpadu, untuk menyajikan informasi pembelian serta informasi yang diperoleh dari kegiatan pengumpulan dan pengolahan data transaksi guna mendukung fungsi operasional manajemen pembelian dan pengambilan keputusan pembelian dalam sebuah organisasi(Sari dkk., 2005). Sementara Fitriyati (2013) menyatakan bahwa sistem akuntansi pembelian digunakan dalam perusahaan untuk pengadaan barang atau jasa yang diperlukan perusahaan baik untuk operasional perusahaan maupun untuk dijual kembali, yang didapat dari pemasok baik dalam negeri maupun luar negeri. Pernyataan tersebut didukung Heripracoyo (2009) yang menyatakan bahwa sistem informasi akuntansi pembelian merupakan sistem yang dibangun untuk mempermudah pelaksanaan pembelian dengan mengotomatisasikan atau mengkomputerisasi keseluruhan maupun beberapa bagian dari proses pembelian tersebut disertai dengan pengendalian atau kontrol atas sistem komputerisasi tersebut.

Mulyadi (2016) menyatakan fungsi yang terkait dalam sistem akuntansi pembelian adalah fungsi gudang, fungsi pembelian, fungsi penerimaan, dan fungsi akuntansi.Fungsi-fungsi tersebut saling berkaitan dan memiliki tugas dan tanggung jawabnya masing-masing.Wardani (2014) menyataan bahwaadanya perangkapan fungsi dapat menyebabkan terjadinya kecurangan dan kehilangan. Disisi lain Suprono (2015) menyebutkan hasil penelitianya bahwa fungsi dari bagian-bagian tersebut saling berkaitan dan mempengaruhi satu sama lain dan apabila ada salah satu dari fungsi tersebut dihilangkan maka proses pembelian tidak dapat berjalan seperti yang diharapkan. Lebih lanjut, Mulyadi (2016) menyatakan bahwatugas dan tanggung jawab fungsi yang terkait sistem informasi akuntansi pembelian diuraikan sebagai berikut.

Masrunik (2017) menyatakan bahwa bagian pembelian merupakan bagian yang sangat penting bila dikaitkan dengan masalah efisiensi pengendalian jumlah biaya yang harus dikeluarkan untuk kegiatan operasional, sehingga perlu dilakukan pengaturan tata laksana atau prosedur pembelian barang. Hal tersebut diperkuat oleh pernyataan Tandean, Mulia, and Setyoadji (2012) yang menyatakan bahwa prosedur sangat penting bagi sebuah perusahaan untuk digunakan sebagai panduan dalam melaksanakan suatu aktivitas agar aktivitas tersebut berjalan dengan teratur dan sesuai dengan ketentuan yang ada. Masih pendapat dia juga mengatakan bahwa prosedur 
yang tidak dijalankan dengan efektif jika hal ini terus berlanjut maka akan timbul kerugian pada perusahaan. Sementara menurut Romney and Steinbart (2015) menjelaskan bahwa jaringan prosedur yang membentuk sisitem informasi akuntansi pembelian adalah, Prosedur permintaan barang; Prosedur permintaan penawaran harga dan pemilihan pemasok; Prosedur Penerimaan Barang, Prosedur Pencatatan Utang, dan Prosedur Distribusi Pembelian.

Dokumen yang digunakan dalam sistem informasi akuntansi harus memadai hal ini seperti yang diungkapkan oleh Bodnar and Hopwood (2006) yang menyatakan bahwa penggunaan dokumen yang memadai untuk membantu memastikan pencatatan atas transaksi dan kejadian. Sementara menurut Romney and Steinbart (2015) ada beberapa dokumen yang digunakan dalam sistem akuntansi pembelian yang adalah Surat Permintaan Pembelian, Surat Permintaan Penawaran Harga, Surat Permintaan Pembelian, surat permintaan pembelian, Laporan Penerimaan Barang, Surat Perubahan Permintaan Pembelian, Catatan Transaksi Pembelian.

Viola dkk. (2017) menyatakan dalam penelitianya bahwa kesalahan dalam proses pencatatan akuntansi yang ada seringkali membuat pimpinan perusahaan kesulitan untuk mengontrol dan mengevaluasi hasil transaksi yang telah berjalan sehingga berdampak pada pencapaian target perusahaan yang tidak stabil. Pernyataan tersebut didukung oleh Wardani (2014) yang menyatakan bahwa prosedur pencatatan berguna untuk terjaminnya harta perusahaan dan sebagai bukti telah terjadi transaksi penjualan.Untuk itu pencatatan akuntansi yang digunakan harus memadai.Sementara Sari dkk. (2005) menyatakan bahwa sistem akuntansi pembelian yang didukung oleh pemanfaatan teknologi informasi, pemakaian catatan-catatan akuntansi yang wajar dapat menjaga kekayaan perusahaan, mengecek ketelitian dan keandalan data akuntansi, mendorong efisiensi serta dipatuhinya kebijakan manajemen yang telah ditentukan.

Selain SIA Pembelian, SIA Penjualan juga memegang peranan penting di dalam perusahaan. SIA Penjualan ini merupakan suatu sistem informasi yang mengorganisasikan serangkaian prosedur dan metode yang dirancang untuk menghasilkan, menganalisa, menyebarkan dan memperoleh informasi guna mendukung pengambilan keputusan mengenai penjualan (Viola dkk., 2017). Sementara Mujahidah (2016) menyatakan bahwa sistem informasi penjualan merupakan sua- tu sistem yang terdiri dari kumpulan orang, peralatan dan prosedur yang memadukan antara pekerjaan mesin (komputer) dan manusia yang menyajikan keakuratan informasi bagi para pemakai dalam membuat keputusan untuk memecahkan masalah didalam perusahaan.Fungsi yang terkait dengan SIA Penjualan menurut Bodnar dan Hopwood (2000) ada enam fungsi terkait dengan sistem informasi akuntansi penjualan sebagai berikut.Fungsi kredit, fungsi penjualan, fungsi gudang, fungsi pengiriman, fungsi akuntansi, fungsi penagihan.Fungsi-fungsi tersebut saling berkaitan dan mempunyai tanggung jawab masingmasing.Mulyadi (2016) menyatakan tidak ada transaksi penjualan yang dilaksanakan secara lengkap oleh hanya satu fungsi.Pernyataan tersebut didukung oleh Devi (2018)yang menyatakan bahwa pemisahan antara fungsi bertujuan untuk menghindari penyimpangan atau penyelewengan dan bertujuan untuk pemfokusan pada masingmasing tanggung jawabnya.

Viola dkk. (2017) menyatakan bahwa proses penjualan yang cukup lama akan berdampak kepada layanan pelanggan tidak maksimal. Hal tersebut diperkuat oleh Lathifah (2015) yang menyatakan bahwa pelaksanaan prosedur yang kurang atau bahkan tidak sesuai dengan standar yang ditetapkan perusahaan akan menjadi masalah bagi perusahaan dan dapat mempengaruhi kinerja perusahaan. Untuk itu diperlukan jaringan prosedur penjualan yang efektif dan efisien.

Sama halnya dengan dokumen yang digunakan pada sistem informasi akuntansi pembelian dalam sistem informasi akuntansi penjualan dokumen yang digunakan juga harus memadai. Devi (2018) penggunaan dokumen bertujuan untuk Quality Control membuat laporan penerimaan, verifikasi dan untuk menghindari penyelewenganpenyelewengan. Sementara menurut Mulyadi (2016) dokumen yang digunakan dalam SIA Penjualan antara lain adalah Surat Order Pengirirman, Tembusan Kredit, Surat Pengakuan (Acknowledgement copy), Surat Muat (Bill), Arsip Pengendalian Pengiriman (Sales Order Follow-up Copy), Arsip Index Silang (Cross-index File Copy), Faktur Penjualan (Customer's Copies), Tembusan Piutang (Account Receivable Copy), Tembusan Analisis (Analisis Copy), Tembusan Wiraniaga (Salesperson Copy), dan Catatan Transaksi Penjualan.

Hasanah dan Siswanto (2012) menyatakan bahwa pencatatan ke dalam catatan akuntansi yang tidak hanya dibebankan kepada karyawan tertentu, tetapi seluruh karyawan yang melakukan kegiatan 
penjualan, menyebabkan perubahan data dalam catatan akuntansi yang tidak dipertanggung jawabkan.Hal tersebut diperkuat oleh Bodnar dan Hopwood (2006) yang menyatakan bahwa pemisahan pencatat transaksi dan penyimpan kekayaan mengurangi peluang kesalahan dan kecurangan atas penggunaan kekayaan perusahaan.Sementara Rawung (2016) menyatakan bahwa penambahan buku gudang perlu dilakukan untuk mencatat jumlah stok barang secara langsung untuk meminimalisir keterlambatan pemesanan barang yang telah habis dan mencatat keluar masuknya barang sehingga tidak terjadi kesalahan dalam penghitungan jumlah barang yang ada digudang.Dengan demikian kelengkapan catatan yang memadai sangat diperlukan.

Hal lain yang perlu menjadi perhatikan terkait dengan SIA Pembelian dan Penjualan adalah sistem pengendalian internal (SPI). Pengendalian internal merupakan suatu cara untuk mengawasi, mengarahkan, dan mengukur sumber daya suatu organisasi atau perusahaan (Devi, 2018).Pernyataan tersebut diperkuat oleh Lathifah (2015) yang menyatakan bahwa pengendalian dibutuhkan untuk mengetahui ada atau tidaknya penyimpangan dari rencana atau kebijakan yang telah ditetapkan oleh perusahaan.Penerapan sistem akuntansi pembelian dan penjualan yang didukung oleh sistem pengendalian intern dapat menghasilkan suatu informasi yang benar dan dapat dipercaya, sehingga sistem tersebut benarbenar bermanfaat terutama bagi perusahaan (Sari dkk., 2005). Hal tersebut diperkuat oleh pernyataan Ambarwati and Isharijadi (2012) yang menyatakan bahwa lemahnya unsur pengendalian intern yang diterapkan terutama pada sistem pembelian menjadi salah satu penyebab permasalahan yang timbul pada perusahaan.

\section{METODE PENELITIAN}

Penelitian ini termasuk dalam kategori studi kasus dengan menggunakan analisis deskriptif. Rawung (2016) menyatakan bahwa metode penelitian deskriptif kualitatif yaitu penelitian yang memberikan gambaran, uraian, penjelasan yang tepat secara obyektif tentang keadaan sebenarnya dari obyek yang diteliti. Dengan demikian akan dapat diketahui kondisi dari kasus yang diteliti serta bagaimana mengatasi permasalahan yang muncul. Jenis penelitian ini peneliti pilih, karena obyek yang digunakan dalam penelitian ini adalah CV. Tri Kencana yang saat ini sedang menghadapi permasalahan terkait dengan SIA pembelian dan penjualannya. Oleh karena itu peneliti akan menggambarkan kondisi sesungguhnya dari perusahaan ini, kemudian menganalisisnya dan memberikan solusi atas persoalan yang dihadapi oleh perusahaan.

Penelitian ini dilakukan pada CV. Tri Kencana Cilegon-Banten, dengan alasan perusahaan ini bergerak dalam bidang supplier dan jasa sehingga kegiatan utamanya adalah melakukan pembelian dan penjualan barang-barang electrical, mechanical,dan pipping. Dengan demikian pemilihan obyek ini peneliti anggap sesuai dengan topik yang dipilih. Adapun data yang dikumpulkan peneliti peroleh dari berbagai pihak dalam perusahaan yang berkaitan dengan SIA pembelian dan penjualan. Pihak-pihak yang memberikan data untuk penelitian ini adalah (1) Pemilik/Pemimpin perusahaan, dari pemilik atau pemimpin perusahaan diperoleh data tentang deskripsi perusahaan, struktur organisasi, dan data mengenai daftar perusahaan-perusahan yang menjalin kerjasama dengan CV. Tri Kencana. (2) Kepala bagian general admin \& finance, Dari kepala bagian general admin \& finance diperoleh data mengenai prosedur pencatatan dan pengelolaan financial, serta rincian tugas dan tanggung jawab khususnya bagian general admin \& finance. (3) Kepala bagian oeprasional, Dari kepala bagian oprasional diperoleh data mengenai bagaimana jaringan prosedur pembelian dan penjualan yang membentuk sistem serta rincian tugas dan tanggung jawab khususnya bagian operasional. (4) Kepala bagian marketing, dari kepala bagian marketing diperoleh data mengenai prosedur penjualan serta rincian tugas dan tanggung jawab khususnya bagian marketing, serta (5) Bagian Teknisi, dari bagian teknisi diperoleh data mengenai bagaimana prosedur penerimaan barang dan pengawasan pengiriman barang, serta rincian tugas dan tanggung jawab khususnya bagian teknisi.

Selain informasi dari pihak yang sudah disebutkan sebelumnya, peneliti juga memperolah data dari dokumen yang ada di perusahaan seperti struktur organisasi, faktur-faktur pembelian dan penjualan, kartu pesanan pembelian dan penjualan, nota kredit, serta catatan-catatan atau dokumentasi lainya yang digunakan oleh perusahaan. Data dikumpulkan melalu tiga cara yaitu observasi partisipatif, wawancara, dan dokumentasi.

Observasi partisipatif peneliti lakukan agar hal-hal yang tidak tampak di permukaan dapat peneliti rasakan. Peneliti ikut bekerja di perusahaan selama satu bulan dan magang di semua bagian yang ada dalam perusahaan, dengan demikian peneliti dapat melihat, merasakan, dan 
mengungkap hal-hal yang terkait topik yang dibahas.

Wawancara dilakukan kepada pihak-pihak yang telah disebutkan sebelumnya di saat sedang istirahat atau santai dengan menyiapkan daftar pertanyaan yang digunakan untuk mengarahkan percakapan agar tidak kehilangan arah. Wawancara dilakukan saat peneliti terlibat langsung dalam setiap aktivitas, jika dirasa ada hal-hal yang menimbulkan pertanyaan di benak peneliti, maka dilakukan tanya jawab dengan pihak terkait. Pada awalnya peneliti ditempatkan pada bagian general admin \& finance untuk memperoleh informasi mengenai prosedur pemesanan barang, dokumentasi dan prosedur pencatatan akuntansi. Kemudian peneliti ditempatkan di bagian oprasional untuk memperoleh informasi mengenai prosedur dan dokumen terkait pembelian barang.Selanjutnya peneliti dipindahkan kebagian teknisi. Selanjutnya di bagian teknisi. Penempatan peneliti di bagian teknisi dimaksudkan untuk memperoleh informasi mengenai prosdur dan dokumen terkait pemeriksan dan pengiriman barang. Selain itu peneliti juga ditempatkan pada bagian penjualan untuk memperoleh informasi mengenai prosedur dan dokumen terkait penjualan barang. Kesemua aktifitas ini dilakukan agar peneliti memperoleh informasi secara lengkap dan utuh mengenai situasi yang terjadi di perusahaan

Cara lain yang peneliti lakukan untuk memperoleh data yang dibutuhkan adalah melalui wawancara dengan pihak-pihak terkait. Untuk mememudahkan dan mengarahkan wawancara digunakan daftar pertanyaan sebagai pedoman pelaksanaannya agar percakapan dengan pihak-pihak terkait dapat terarah pada topik bahasan. Aktivitas wawancara peneliti lakukan dalam suasana yang santai dengan rasa keakraban dengan pihak-pihak terkait.Wawancara dilakukan di sela-sela aktifitas rutin, atau di saat ada hal-hal yang menggelitik benak peneliti karena aktifitas tertentu.Selain itu wawancara peneliti lakukan pula di waktu senggang saat makan siang atau istirahat agar pihak yang diwawancarai tidak merasa diinterogasi. Dari wawancara tersebut peneliti memperoleh berbagai data terkait dengan SIA pembelian dan penjualan yang diterapkan pada CV. Tri Kencana. Hasil wawancara ini peneliti padukan dengan cara perolehan data lainnya yaitu melalui observasi partisipatif dan dokumentasi.

Selain kedua cara di atas, peneliti juga melakukan pengumpulan data melalui Dokumentasi. Dokumentasi yang dimaksudkan di sini adalah data yang diperoleh secara tertulis (berwujud) atau dari setiap bagian yang ada untuk melengkapi data dari wawancara dan observasi. Data ini berupa berupa foto-foto, rekaman suara, dan catatan tertulis sebagai alat bukti resmi yang dapat dipertanggungjawabkan. Data diperoleh dengan cara mengambil atau mengutip dokumen atau catatan yang berkaitan dengan SIA pembelian dan penjualan.

\section{HASIL DAN PEMBAHASAN}

SIA pembelian dan penjualan pada CV. Tri Kencana dapat dikatakan masih belum sempurna. Hal ini tampak dari berbagai komponen sistem yang ada. Berikut ini disajikan gambar prosedur pembelian yang dilakukan oleh CV Tri Kencana.

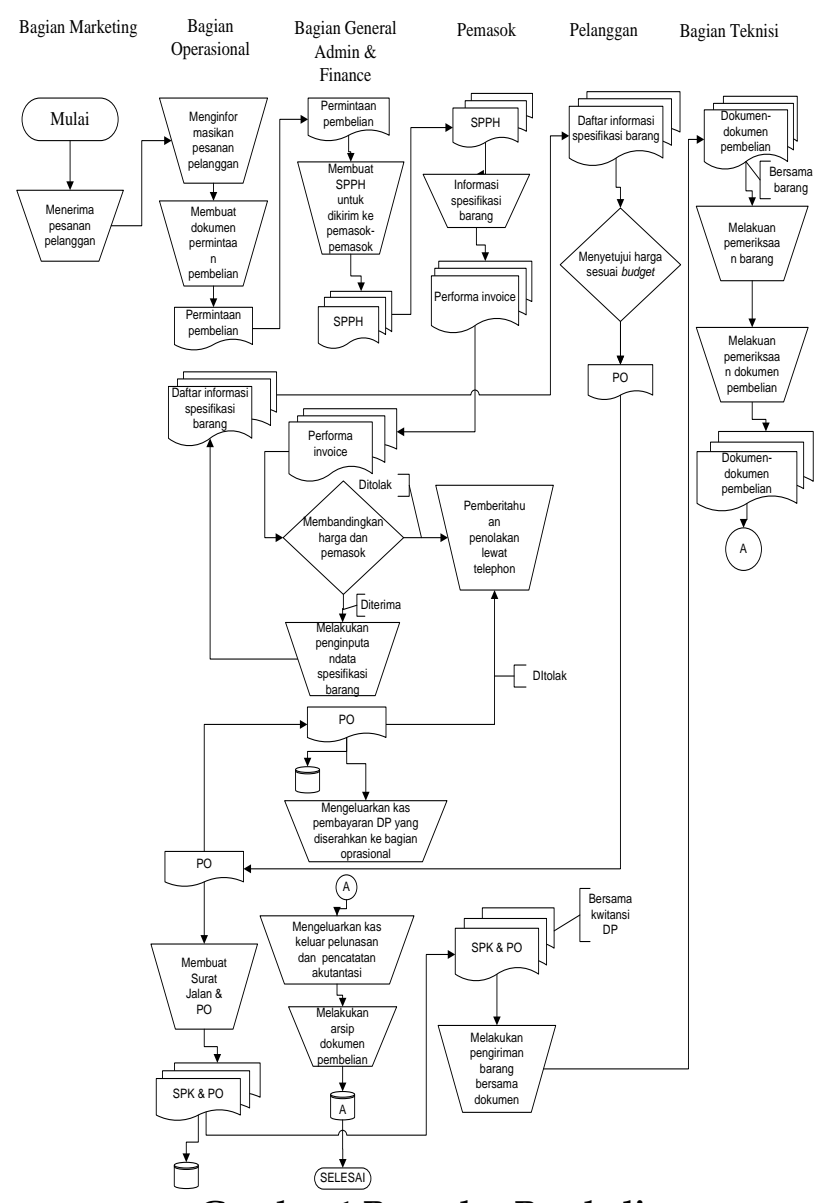

Gambar 1 Prosedur Pembelian

Penjelasan gambar 1 yang merupakan "flow chart" SIA pembelian diuraikan sebagai berikut.

1) Pemesanan barang yang dilakukan oleh pelanggan kepada CV. Tri Kencana dilakukan melalui bagian marketing. 
2) Bagianmarketing menginformasikan pesanan tersebut ke bagian operasional.

3) Bagian operasional membuatkan surat permintaan pembelian yang selanjutnyadikirimkan ke bagian general admin $\mathcal{E}$ finance $(G A \mathcal{E} F)$

4) bagian $G A \& F$ membuat surat permintaan penawaran harga (SPPH) kepada pemasok. Pemasok yang dikirimi SPPH adalah pihakpihak yang telah menjalin kerjasama dengan perusahaan. Pengiriman SPPH ini dilakukan melalui email. Hal ini dilakukan untuk menghemat waktu dan biaya, yang tujuannya untuk memperoleh informasi mengenai harga dan spesifikasi atas barang yang dipesan.

5) Pemasok akan membalas email tersebut dan menyerahkan performa invoice yang dibutuhkan perusahaan.

6) Bagian $G A \& \mathcal{E}$ melakukan pembandingan harga-harga dari para pemasok tersebut dan membuat keputusan pemasok mana yang diterima dan mana yang ditolak. Pemasok yang ditolak akan diberi tahu melalui telepon.

7) Bagian $G A \&$ Fmenginput data harga serta informasi lainya dari pemasok-pemasok yang diterimake dalamdaftar informasi spesifikasi barang. Dokumen tersebut kemudiandiberikan kepada bagian operasional untuk dikirimkan ke pelanggan.

8) Pelanggan akan menyeleksi harga yang sesuai dengan kriterianya, kemudian membuat purchase order (PO) dan diserahkan ke bagian operasional.

9) Bagian operasional membuat PO dan Surat Perintah Kerja (SPK)

10) Bagian operasional juga menginformasikan mengenai pemasok yang dipilih pelanggan dan pembayaran uang muka yang harus dikeluarkan atas barang yang akan dipesan ke bagian $G A \mathcal{E} F$ dengan mengirimkan $\mathrm{PO}$ asli dari pelanggan.

11) Bagian GA EF memberitahu pemasok yang ditolak pelanggan melalui telephon dan mengeluarkan kas keluar pembayaran uang muka yang diserahkan ke bagian operasional. Hal ini seperti yang diungkapkan oleh kepala bagian operasional dari penjelasan pada saat diwawancarai yang mengatakan bahwa: "Untuk pembayaran barang kami melakukan secara cash by cash pesen barang terlebih dahulu dengan pembayaran $30 \%$ setelah barang sampai ke gudang Jakarta baru dibayar sisanya"( Wawancara, 6 Februari 2019 )". PO dari pelanggan kemudian diarsipkan.
12) Bagian operasional kemudian akan melakukan pembelian sesuai pesanan pelanggan. Sebagaimana hasil wawancara peneliti dengan pihak perusahaan sebagai berikut: "Acuan kami dalam pembelian barang dilakukan setelah surat pesanan pembelian dari klien turun, ini dilakukan untuk kepastian pemesanan" ( Wawancara, 6 Februari 2019 )". Pembelian pesanan dilakukan dengan mengirimkan 2 lembar surat yaituSPK dan PO disertakan juga bukti pembayaran yang diserahkan ke pemasok sebagaibukti pemesan barang. Dokumen tersebut sebelumnya telah dibuatkan salinan untuk disimpan sebagai arsip.

13) Pemasok kemudian melakukan pengiriman barang pesanan dengan menyertakan dokumen-dokumenya kepada CV. Tri Kencana yang diserahkan ke bagian teknisi.

14) Bagian teknisi kemudian melakukan pemeriksaan kelengkapan dokumen-dokumen dan pemeriksaan terhadap barang pesanan mengenai fisik, kualitas, dan spesifikasi barang.

15) Apabila barang pesanan dan dokumendokumen penjualan dinyatakan dalam keadaan baik. Bagian teknisi menyerahkan dokumendokumen pembelian ke bagian $G A \mathcal{E} F$.

16) Bagian $G A \& \&$ mengeluarkan kas kluar pelunasan pembayaran dan melakukan pencatatan akuntansi. Hal ini terungkap dari penjelasan bagian general admin $\mathcal{E}$ finance pihak yang diwawancarai yang mengatakan bahwa : "kami melakukan pencatatan bukti kas masuk dan kas keluar secara langsung setelah dokumen pembelian dan penjualan telah kami terima"( Wawancara, 6 Februari 2019 )". Dokumen tersebut kemudian diarsipkan sebagai tanda bukti transaksi pembelian barang yang dilakukan oleh perusahaan.

Dari prosedur yang ada tampak bahwa surat permintaan penawaran harga dibuat oleh bagian general admin \& finance (GAF) yang kemudian dikirimkan ke bagian operasional. Hal ini menunjukkan ketidakefisienan, karena bagian operasional harus menunggu Surat Permintaan Penawaran Harga (SPPH) dari bagian GAF. Berdasarkan pembagian tugas yang ditetapkan, bagian GAF mempunyai tugas dan tanggungjawab yang cukup banyak dibandingkan dengan bagian lain dan yang mengerjakan hanya satu orang.

Aliran dokumen yang harus melalui bagian GAF seringkali memakan waktu cukup lama sehingga aliran dokumen menjadi tidak efektif. Disamping itu dokumen SPPH tidak diarsipkan sehingga apabila dibutuhkan data mengenai 
jumlah pengeluaran SPPH, pihak yang membutuhkan akan menemui kesulitan. Sementara itu, pada proses pemeriksaan barang masih belum dibuatkan dokumen laporan penerimaan barang yang sesuai. Berdasarkan pembagian tugas dan wewenang yang ditetapkan, ternyata ada perangkapan tugas dan fungsi di bagian ini. Di bagian Operasional rincian tugas tidak terlalu banyak dan dikerjakan oleh dua orang, sedangkan di bagian marketing dilakukan oleh tiga orang. Hal ini terungkap dari penjelasan pihak yang diwawancarai yang mengatakan bahwa: "tugas yang dilakukan bagian general admin \& finance cukup banyak, dimana kami menjalankan tugas dan bertanggungjawab untuk mencatat perpajakan, dokumentasi, menerima informasi pesanan dan informasi lainya dari klien, melakukan penagihan kas, mencatat bukti kas keluar dan kas masuk perusahaan, serta membuat laporan keuangan perusahaan"(Wawancara, 6 Februari 2019)".

Dari uraian struktur organisasi dan hasil wawancara menunjukkan bahwa bagian ini melakukan perangkapan fungsi yaitu sebagai penagih, pencatat, pembuat laporan keuangan, dan menerima info pesanan pembelian yang dilakukan oleh pelanggan.Hal ini menunjukkan sistem pengendalian internal yang lemah. Lebih lanjut dikatakannya bahwa: " kami bertanggung jawab untuk mengelola informasi pemesanan pembelian langsung ke kantor dan informasi lainnya, membuat dan mengelola dokumen, serta melakukan pencatatan akuntansi keuangan perusahaan".

Di sisi lain pada struktur organisasi ini ada hal yang kurang efektif dan efisien dalam pengelolaannya. Seperti pada penamaan departemen yang masih belum tepat dimana manager oprasional dan manager marketing seharusnya diganti nama dengan bagian oprasional dan bagian marketing sehingga dapat memperjelas antara manager dan staf-staf yang ada. Sementara itu pada bagian business and development mempunyai tugas dan fungsi yang sama persis dengan bagian marketing, hanya saja berbeda dalam pengelolaannya. Bagian business \& development berhubungan dengan perusahaan yang berskala besar, tetapi dalam struktur organisasi digambarkan secara terpisah.

Dokumen penerimaan barang tidak menunjukkan bahwa barang yang diterima dari pemasok telah memenuhi kuantitas dan kualitas yang sesuai dengan dokumen permintaan pembelian. Permasalahan lain juga terdapat pada proses penyiapan dokumen penjualan. Dokumen penjualan saat ini termasuk dalam tugas dan tanggungjawab bagian general admin \& finance yang secara fungsi seharusnya menjadi tugas bagian penjualan/marketing.

Di sisi lain catatan akuntansi yang digunakan selama ini masih belum memadai, karena perusahaan hanya menggunakancatatan berdasarkan register bukti kas keluar dan masuk, selain itu proses pencatatan akuntansi masih dilakukan secara manual (belum terkomputerisasi) akibatnya akan sangat rentan terhadap kesalahan catat/pembukuan. Kondisi ini terungkap saat wawancara dengan bagian general admin \& finance yang mengatakan bahwa:"kalau untuk jurnalpembelian dan penjualankami tidak melakukan pencatatan.Pencatatan hanya dilakukan tidak secara spesifik dan masih belum menggunakan aplikasi"(Wawancara, 6 Februari 2019)". Kondisi seperti ini tentu saja menyulitkan pihak manajemen dalam melakukan pengendalian. Akibatnya akan sangat mungkin timbul penyalahgunaan wewenang serta kecurangan-kecurangan yang mungkin akan dilakukan oleh karyawan di perusahaan tersebut.

Selanjutnya disajikan flowchart untuk SIA Penjualan yang tampak pada gambar 2 berikut ini.

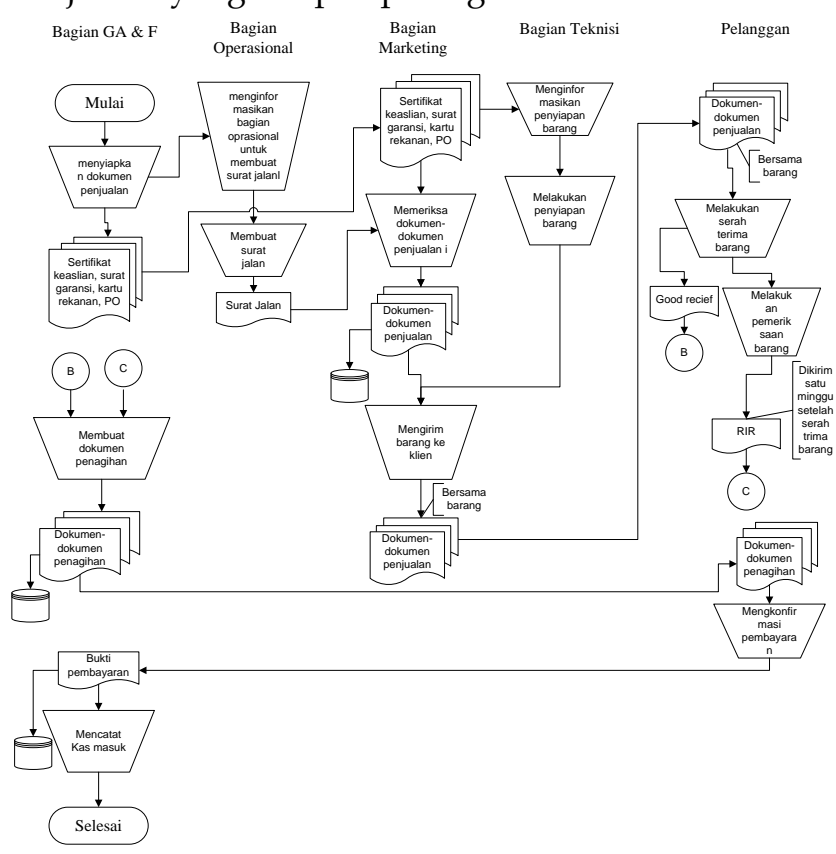

\section{Gambar 2. Prosedur Penjualan CV Tri Kencan}

Gambar 2 di atas menunjukkan bagan alir dari SIA penjualan yang ada pada CV. Tri Kencana. Perlu diketahui bahwa CV. Tri kencana merupakan perusahaan supplier yang tidak mempunyai gudang sehingga tidak menyimpan stok di gudang sehingga barang yang dibeli dari pemasok langsung dijual atau dikirimkan ke pelanggan. Berikut 
ini uraian tentang penjelasan gambar 2.

1) Bagian GAF memberikan dokumen penjualan dan menginformasikan ke bagian operasional untuk dibuatkan surat jalan sebagai kelengkapan dalam proses pengiriman.Dokumen-dokumen tersebut kemudian diserahkan ke bagian marketing.

2) Bagian marketing melakukan pemeriksaan kelengkapan dokumen penjualan serta menyimpan salinan dokumen penjualan untuk dijadikan arsip. Disisi lain bagian marketing juga menginformasikan kepada bagian teknisi untuk menyiapkan barang pesanan yang akan dikirim ke pelenggan.

3) Bagian teknisi kemudian melakukan penyiapan barang yang akan dikirim. Kemudian barangdikirim bersama dengan dokumendokumen penjualan.Proses pengiriman dilakukan oleh dua bagian yaitu bagian teknisi dan bagian marketing.

4) Selanjutnya dilakukan serah terima barang ke pelanggan. barang pesananmasuk ke dalam gudang perusahaan pelanggan kemudian pelanggan mengeluarkan surat good receipt (surat serah terima barang).

5) Satu minggu setelah serah terima barang, barang tersebut kemudian dicek kembali oleh bagian inspeksi gudang pelanggan dan dikeluarkan dokumen Receiv Inpaction Report yang menyatakan bahwa barang masuk dalam keadaan layak.Hal tersebut diungkapkan oleh kepala bagian operasional yang pada saat diwawancarai mengatakan bahwa :"Surat Receiv Inpaction Report turun satu minggu setelah barang masuk ke dalam gudang" (Wawancara, 6 Februari 2019 )". Surat RIR kemudian dikirim ke CV. Tri Kencana yang diterima oleh bagian general admin $\mathcal{E}$ finance yang juga menjalankan tugas sebagai bagian penagihan.

6) Bagian general admin $\mathcal{E}$ financekemudian menyiapkan dan membuat dokumen penagihan. Dokumen-dokumen pengihan yang digunakan sebagai berikut.
a) BTTD
Dokumen yang digunakan sebagai bukti tanda terima dokumen
b) Invoice Penjualan
Dokumen tagihan kepada pelanggan atas pembelian suatu barang atau jasa.
c) Good Receipt
Dokumen yang digunakan untuk surat serah terima barang.
d) Surat Jalan

Dokumen bukti pengiriman yang memberi kejelasan dan rincian barang yang dikirim

e) Receiv Inpaction Report

Dokumen yang menyatakan bahwa barang yang masuk dalam keadaan layak.

f) Faktur Pajak

Dokumen bukti pungutan pajak yang dibuat oleh pengusaha kena pajak yang melakukan penyerahan barang atau kena pajak.

g) Purchase Order

Dokumen surat yang berisi pesanan untuk memebeli atau memesan barang yang dikirim oleh pembeli kepada penjual.

Hal tersebut diungkapkan oleh kepala bagian operasional yang pada saat diwawancarai mengatakan bahwa :"Dokumen yang digunakan dalam penagihan kas itu ada BTTD, invoice penjualan, good receipt, surat jalan, receiv inpaction report, faktur pajak dan pesanan pembelian" ( Wawancara, 6 Februari 2019 )".

7) Dokumen-dokumen tersebut kemudian dikirimkan ke pelanggan dengan menyerahkan langsung ke bagian administrasi pelanggan.Bagaian general admin $\mathcal{E}$ finance juga menyimpan salinan dokumen penagihan ke dalam arsip yang nantinya digunakan sebagai bukti.

8) Pelanggan kemudian mengkonfirmasi pembayaran dengan mengirimkan bukti pembayaran.

9) Bagian GAF mencatat kas masuk dan bukti pembayaran tersebut diarsipkan sebagai tanda bukti kas masuk dari transaksi penjualan barang yang dilakukan oleh perusahaan.

Memperhatikan penjelasan pada prosedur penjualan permasalahan yang tampak mirip dengan prosedur pembelian, yaitu adanya perangkapan fungsi terutama di bagian GFA, belum ada pencatatan akuntansi secara rinci kecuali catatan tentang aliran kas, dan pengarsipan dokumen yang masih kurang. Berdasarkan analisis yang telah dilakukan pada SIA pembelian dan penjualan yang sedang berjalan pada CV. Tri Kencana dan perolehan temuan yang masih tidak sesuai dengan SIA pembelian dan penjualan yang seharusnya diterapkan, berikut ini peneliti menggambarkan 
situasi yang dihadapi dan solusi yang ditawarkan untuk penyelesaian masalah, dengan merangkumnya melalui tabel 1 berikut ini.

Tabel 1 Permasalahan dan Solusi

\begin{tabular}{|c|c|c|}
\hline $\begin{array}{l}\text { Kompo- } \\
\text { nen SIA }\end{array}$ & Uraian & Solusi \\
\hline $\begin{array}{l}\text { Struktur } \\
\text { Organ- } \\
\text { isasi yang } \\
\text { tidak } \\
\text { efektif } \\
\text { dan } \\
\text { efisien }\end{array}$ & 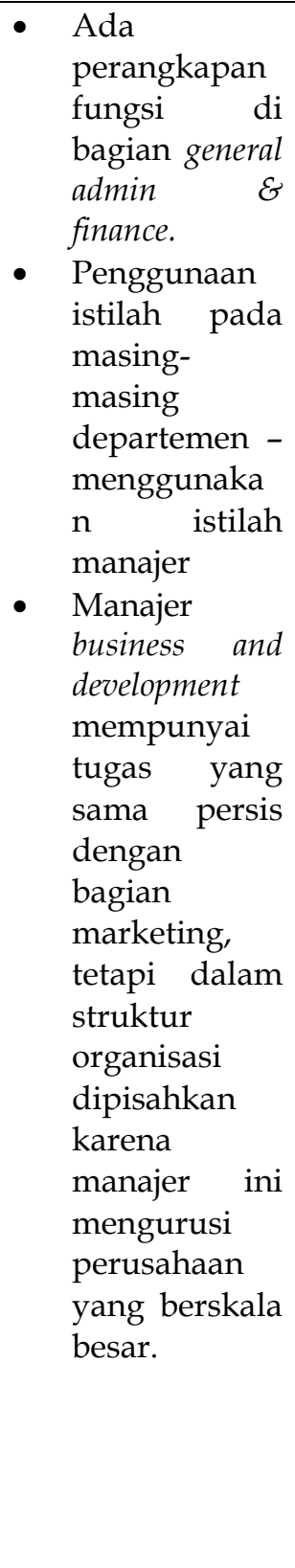 & $\begin{array}{l}\text { - Pembagian } \\
\text { tugas } \\
\text { sebaiknya } \\
\text { seimbang di } \\
\text { setiap bagian } \\
\text { agar tidak } \\
\text { menimbulkan } \\
\text { iri hati pada } \\
\text { pihak lain. } \\
\text { Istilah } \\
\text { manajer yang } \\
\text { digunakan } \\
\text { pada setiap } \\
\text { departemen } \\
\text { menujukkan } \\
\text { satu orang } \\
\text { yang } \\
\text { memimpin } \\
\text { departemen } \\
\text { tersebut, } \\
\text { sebaiknya } \\
\text { diganti } \\
\text { dengan } \\
\text { "Bagian/depa } \\
\text { rtemen”. } \\
\text { Bagian } \\
\text { Marketing dan } \\
\text { Business and } \\
\text { Development } \\
\text { seharusnya } \\
\text { dijadikan satu } \\
\text { departemen } \\
\text { karena tugas } \\
\text { dan fungsinya } \\
\text { sama, hal ini } \\
\text { dimaksudkan } \\
\text { untuk } \\
\text { efisiensi. }\end{array}$ \\
\hline $\begin{array}{l}\text { Penggun } \\
\text { aan } \\
\text { dokumen } \\
\text { belum } \\
\text { optimal }\end{array}$ & $\begin{array}{l}\text { - SPPH harus } \\
\text { menunggu } \\
\text { otorisasi dari } \\
G \text { AE F dan } \\
\text { tidak } \\
\text { diarsipkan. } \\
\text { - Tidak ada } \\
\text { dokumen } \\
\text { pada proses }\end{array}$ & $\begin{array}{l}\text { - } \text { Seharusnya } \\
\text { SPPH tidak } \\
\text { perlu melalui } \\
\text { bagian GA \& } \\
\text { F, bagian ini } \\
\text { cukup } \\
\text { mengarsipkan } \\
\text { saja dokumen } \\
\text { tersebut }\end{array}$ \\
\hline
\end{tabular}

\begin{tabular}{|c|c|c|}
\hline & $\begin{array}{l}\text { penerimaan } \\
\text { barang. } \\
\text { Dokumen } \\
\text { penerimaan } \\
\text { barang tidak } \\
\text { menunjukkan } \\
\text { rincian } \\
\text { tentang } \\
\text { kuantitas dan } \\
\text { kualitas } \\
\text { sesuai } \\
\text { permintaan } \\
\text { pembelian. } \\
\text { Dokumen } \\
\text { penjualan } \\
\text { dibuat oleh } \\
\text { GA \& F. }\end{array}$ & $\begin{array}{l}\text { sebagai } \\
\text { bagian dari } \\
\text { tugasnya. } \\
\text { Oleh karena } \\
\text { itu dokumen } \\
\text { ini perlu } \\
\text { dibuat } \\
\text { minimal } \\
\text { rangkap dua, } \\
\text { karena yang } \\
\text { satu ke } \\
\text { diserahkan ke } \\
\text { pemasok dan } \\
\text { yang lain } \\
\text { diarsipkan } \\
\text { oleh GA \& F. } \\
\text { Dokumen } \\
\text { penerimaan } \\
\text { barang perlu } \\
\text { dirinci } \\
\text { spesifikasinya } \\
\text { agar bisa } \\
\text { saling } \\
\text { mengoreksi. } \\
\text { Dokumen } \\
\text { penjualan } \\
\text { seharusnya } \\
\text { dibuat oleh } \\
\text { bagian } \\
\text { marketing, } \\
\text { dan arsipnya } \\
\text { diserahkan ke } \\
\text { GA \& F. }\end{array}$ \\
\hline $\begin{array}{l}\text { Pembu- } \\
\text { atan cata- } \\
\text { tan } \\
\text { akuntansi } \\
\text { yang } \\
\text { belum } \\
\text { memadai }\end{array}$ & $\begin{array}{ll}\text { - } & \text { Catatan } \\
\text { dibuat secara } \\
\text { manual } \\
\text { - Catatan } \\
\text { hanya } \\
\text { didasarkan } \\
\text { pada bukti } \\
\text { register kas } \\
\text { masuk dan } \\
\text { keluar }\end{array}$ & 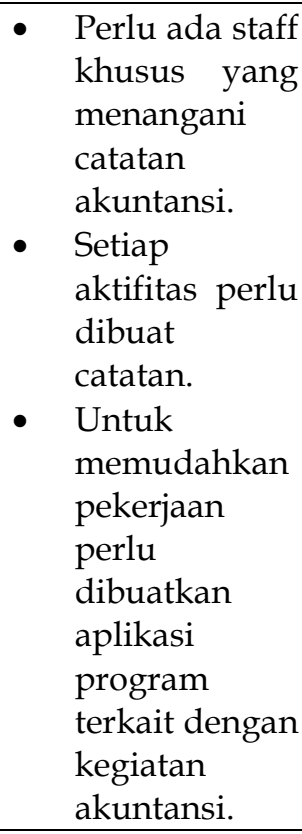 \\
\hline
\end{tabular}




\section{SIMPULAN}

Berdasarkan hasil penelitian dan pembahasan yang telah dilakukan pada SIA pembelian dan penjualan di CV. Tri Kencana masih perlu melakukan penyempurnaan baik pada struktur organisasi, penggunaan dokumen, maupun pencatatan yang harus dilakukan.Hal ini dimaksudkan agar kegiatan dapat berjalan secara lebih efektif dan efisien.Tidak ada lagi bagian yang harus mengerjakan tugas yang sangat banyak, sedangkan di bagian lain ada yang tugasnya lebih sedikit.

Perusahaan selama ini tidak melakukan pengarsipan terhadap dokumen-dokumen penting sehingga menyulitkan penelusuran dan pengambilan keputusan. Selain itu pencatatan yang dilakukan hanya terbatas pada aliran kas keluar dan masuk, catatan lain yang seharusnya juga dibuat belum dilakukan. Pengendalian intern di perusahaan ini masih sangat lemah, karena staf yang diserahi tanggung jawab tidak dilakukan pengontrolan atas kinerjanya.Hal ini berakibat sering terjadi kelalaian dalam penyelesaian kegiatan yang berdampak pula pada kepuasan pelanggan.

Di sisi lain peneliti mengalami keterbatasan dalam waktu pengumpulan data, karena magang yang dilakukan hanya satu bulan, sedangkan aktifitas yang ada di perusahaan cukup banyak dan beragam, sehingga waktu yang digunakan di setiap bagian sangat terbatas. Oleh karena itu persoalan yang terungkap hanya terbatas kejadian saat peneliti berada di bagian tertentu.

\section{REFERENCES}

Alianto, H., Wijaya S. F. dan Arlan, F., (2012), An Analysis Of Sales Information System and Competitive Advantage (Study Case of UD. Citra Helmet). International Journal of Comunication \& Tekhnologi Informasi (Komit), Vol 6, page 1-7.

Ambarwati, F. W. dan Isharijadi, (2012), Analisis Sistem Informasi Akuntansi Pembelian Bahan Baku Secara Tunai Guna Meningkatkan Efektivitas Pengendalian Intern Pada PT. Dwi Mulyo Lestari Madiun. Jurnal Akuntansi dan Pendidikan, Vol 1, page 79.

Bodnar, G. H., dan Hopwood, W. S., (2000), Sistem Informasi Akuntansi, Jakarta: Salemba Empat

Informasi Akuntansi, Yogyakarta: ANDI

Devi, Z. R., (2018) Analisis Sistem Akuntansi Pembelian Bahan Baku dan Pengeluaran Kas Dalam Upaya Meningkatkan
Pengendalian Internal. Adminitrasi Bisnis, Vol 58, page 36-45.

Fitriyati, (2013), Sistem Akuntansi Pembelian BBM Pada SPBU 14.2856118 HJ. Rosniati Kecamatan Rambah Samo. Cano Ekonomos, Vol 2, page 44-58.

Garcia, M. M. D., Nangoi, G. B. dan Tirayoh, V. Z., (2016), Evaluasi Penerapan Sistem Informasi Akuntansi Atas Silklus Pendapatan Pada PT. PLN ( PERSERO) Area Manado. Jurnal EMBA, Vol 4, page 826-836.

Hasanah, N. F., dan Siswanto, M. P., (2012), Perencanaan Sistem Akuntansi Penjualan Tunai Terkomputerisasi Pada Apotek Gedong Kuning, Jurnal Nominal, Vol 1, page 1-7.

Hastoni dan Aprilisabeth, D. S., (2008), Peranan Sistem Informasi Akuntansi Penjualan Kredit Dalam Meningkatkan Efektivitas Pengendalian Intern Piutang dan Penerimaan Kas. Jurnal Ilmiah Ranggagading, Vol 8, page 30-36.

Heripracoyo, S., (2009), Analisis dan Perancangan Sistem Informasi Akuntansi Pembelian dan Persediaan Pada PT. Oliser Indonesia. Seminar Nasional Aplikasi Tekhnologi Informasi, 93.

Kusasi, D. dan Rahman, Y., (2018), Analisis Sistem Informasi Akuntansi Pembelian dan Penjualan pada CV. Kerja Sama di Marabahan. KINDAI, Vol 14, page 122-126.

Lathifah, R., (2015), Analisis Sistem Akuntansi Penjualan dan Penerimaan Kas Dalam Upaya Untuk Mendukung Pengendalian Internal, Jurnal Adminitrasi Bisnis, Vol 28, page 1-12.

Masrunik, I., (2017), Analisis Sistem dan Prosedur Akuntansi Pembelian Guna Meningkatkan Efektivitas Pembelian Rubber Seal. Jurnal Benefit, Vol 4 No 16.

Mindhayani, I., dan Purnomo, H., (2016), Analisis Sistem Kerja Terhadap Produktivitas Karyawan. Jurnal PASTI, Vol 10, page 98107.

Mujahidah, A., (2016), Analisis Sistem Informasi Akuntansi Penjualan Pada PT. HADJI KALLA ( TOYOTA ) CABANG PINRANG. Jurnal Riset Edisi $V$ UNIBOS MAKASAR, Vol 4, page 90 .

Mulyadi, (2016), Sistem Akuntansi Edisi 4, Jakarta: Salemba Empat.

Rawung, F. R., (2016), Analisis Efektivitas Sistem 
Akuntansi Penjualan dan Penerimaan Kas Pada PT. Surya Wenang Indah Manado. Berkala Ilmiah Efisiensi, Vol 16, page 1-11.

Romney, M. B., dan Steinbart, P. J., (2004), Sistem Informasi Akuntansi Edisi 9, Jakarta: Salemba Empat.

(2015), Sistem Informasi Akuntansi Edisi 13, Jakarta Selatan: Salemba Empat.

Sari, A. R., Djazari, M. dan Sukirno, D. S., (2005) Analisis Sistem Akuntansi Pembelian Pada Hotel Quality Yogyakarta. Jurnal Pendidikan Akuntansi Indonesia, Vol 3 No 2, page 102 123.

Suprono, H., (2015). Analisis Pelakasanaan Sistem Akuntansi Pembelian Untuk Meningkatkan Evektivitas Sistem Pengendalian Manajemen. Jurnal Riset Mahasiswa Akuntansi, Vol 20, page 1-14.

Tandean, M., Mulia, T. W., dan Setyoadji, A., (2012), Analisis Sistem Pengendalian Internal Pada siklus Pembelian Studi Kasus Pada Hotel JWM, Gema Aktualita,Vol 1, page 26-35.

Viola, M., Ekawati, R. K. dan Wijaya, T., (2017), Analisis dan Perancangan Sistem Informasi Akuntansi Penjualan dan Persediaan Pada PT.XYZ. JUTEI, Vol 1, page 155.

Wardani, W. K., (2014), Analisis Sistem dan Prosedur Penjualan dan Penerimaan Kas Dalam Upaya Peningkatan Pengendalian Intern Perusahaan, Jurnal Adminitrasi Bisnis, Vol 12, page 1-9. 